\title{
Grønthandleren kan blive første udlevering til Indien
}

Lone Theils

Storbritannien og Indien underskrev i 1993 en udleveringsaftale, men det har taget juridiske skænderier med store konsekvenser og næsten tyve år, inden deporteringen af den første inder fra Storbritannien er inden for rækkevidde

For en tilfældig forbipasserende ville det muligvis have set voldsomt ud, da politiet i Manchester slog hårdt ned på den indiske grønthandler Mohammed Hanif Umerji Patel i forstaden Bolton en kold februardag i 2010.

Hvad kunne en grønthandler dog have foretaget sig, der ville retfærdiggøre et så stort politiopbud? Men bag det almindelige indiske navn Patel gemte der sig en næsten tyve år gammel hemmelighed.

Manden, som Boltons borgere kendte som grønthandler, er i virkeligheden Tiger Hanif, en mand, der siden 1993 har været eftersøgt af det indiske politi og Interpol i forbindelse med to terrorangreb i Suran i Gujarat-provinsen.

Provinsen, der er stolt af at være hjemsted for Mahatma Ghandi, har $\mathrm{i}$ årtier haft mere end svært ved at leve op til den indiske landsfaders idealer om fred og pacifisme.

I 1969 blev 2.500 dræbt i de værste sammenstød mellem muslimer og hinduer siden opdelingen i Indien og Pakistan i 1947, og siden da har fortrinsvis religiøst motiverede uroligheder bølget frem og tilbage. Til tider har de været rettet mod kristne, men oftest konflikter mellem hinduer og muslimer.

I 1970'erne var Gujarat forrest i industrialiseringen af Indien, arbejdere strømmede til fra alle andre dele af landet, og det var med til at øge spændingerne mellem Indiens mange befolkningsgrupper og religioner. Og da krisen bed i 1980'erne, blev regionen hårdt ramt. Det pustede igen til uroligheder.

I 1983 menes Tiger Hanif at have 
været med i en aktivistgruppe, der gennemførte to angreb. I det ene tilfælde smed et medlem af gruppen en håndgranat ind på en fyldt markedsplads tæt på en skole. En 8-årig skolepige blev dræbt ved angrebet, der også sårede mange. Han har også, ifølge de indiske myndigheder, været med i planlægningen af og fremskaffelsen af våben til et andet granatangreb. Denne gang på togstationen i Surat. Ingen mistede livet, men 38 mennesker blev såret, heraf flere alvorligt.

Tiger Hanif blev på et tidspunkt arresteret af politiet i Surat, men blev løsladt og flygtede angiveligt til Storbritannien ved hjælp af et falsk pas og har opholdt sig i landet siden.

I maj i år kom sagen for retten $\mathrm{i}$ Westminister. Umiddelbart skulle man tro, at der var tale om en simpel udvekslingssag. Storbritannien og Indien har siden 1993 haft en aftale om udlevering.

Men Tiger Hanif er fast besluttet på at kæmpe mod udleveringen, og når man ser på Storbritanniens og Indiens historie, siden aftalen blev underskrevet af de to regeringer for 19 år siden, tyder meget på, at det ikke nødvendigvis bliver en helt simpel sag at sende den mistænkte terrorist tilbage til retsforfølgelse i Indien.

\section{Chalal-dom spøger}

Den britiske regering har tidligere brændt fingrene på en beslutning om at deportere en mistænkt inder. Det i en sådan grad, at det har fået vidtrækkende konsekvenser for, hvor stort manøvrerum Storbritannien har haft internationalt til at deportere mistænkte terrorister.

Den seneste sag om den terrormistænkte Abu Hamza, der for nylig blev udleveret til USA efter årelang juridisk kamp, der endte ved menneskerettighedsdomstolen i Strasbourg, trækker eksempelvis en lige linje tilbage til aftalen med Indien.

Manden, der kom til at danne præcedens, hedder Karamjit Sigh Chahal, og hans navn kan stadig sende et gys gennem britiske embedsmænd i Home Office, der håndterer udleveringssager.

Chahal stammer fra en anden konfliktfyldt indisk region, Punjab.

I 1971 kom Chalal, der er sikh, illegalt til Storbritannien, men tre år senere fik han opholdstilladelse. Så vidt, så godt.

Problemerne opstod, da han vendte tilbage til Punjab i en periode i 1984. Det var en særdeles blodig episode i Punjabs historie. Efter at en politimand var blevet dræbt i provinsen, stormede politiet Det Gyldne Tempel i Amnitsar. I de efterfølgende kampe blev flere end 1000 sikher dræbt. Chalal, der er sikh, blev arresteret af politiet.

Under sin arrestation blev han udsat for forskellige former for tortur såsom elektrisk stød, en fingeret henrettelse og fik ad flere omgange 
så mange bank, at han mistede bevidstheden.

Det lykkedes ham at flygte tilbage til Storbritannien, hvorfra han blandt andet ledede demonstrationer mod den indiske regering.

I 1990, altså tre år inden aftalen med den indiske regering blev underskrevet, og efter Chalal havde haft opholdstilladelse i 17 år, besluttede den daværende konservative udenrigsminister Douglas Hurd, at Chalal kunne sendes tilbage til Indien efter en paragraf, der fastslår, at regeringen kan deportere mennesker, der 'ikke gavner den almene offentlighed'.

Det blev begyndelsen på seks års tilbageholdelse i et britisk fængsel, mens den juridiske kamp om, hvorvidt Chalal kunne sendes tilbage, blev udkæmpet af advokaterne.

Mens Chalal sad i fængsel, underskrev Indien og Storbritannien aftalen om udveksling, der ville gøre det lettere at udlevere den formodede terrorist.

Men så nemt kom det ikke til at gå. Sagen endte til sidst ved menneskerettighedsdomstolen i Strasbourg, hvor den blev til et principielt spørgsmål om, hvorvidt beskyttelsen af den enkelte person fra eksempelvis en overhængende risiko for tortur vejer tungere end hensynet til den almene befolknings sikkerhed fra eksempelvis en risiko for at have en potentiel terrorist iblandt sig.

Sagen i Strasbourg faldt ud til Chalals fordel. Domstolen fastslog i
1996, at Menneskerettighedernes artikel 3, der fastslår, at "ingen skal udsættes for tortur, umenneskelig eller nedværdigende behandling", vejer tungere end den potentielle risiko for terror eller kriminalitet.

\section{Ingen torturrisiko}

Chalal lever nu en fredsommelig og upåagtet tilværelse i Storbritannien og er aldrig siden vendt tilbage til Indien. Men implikationerne af hans dom har ikke været fredsommelige.

Afgørelsen har siden forfulgt Storbritannien i forbindelse med tilbageholdelse af formodede terrorister som eksempelvis Abu Hamza.

Britiske embedsmænd og debattører peger enstemmigt på Chalal-afgørelsen som starten på Storbritanniens problemer med at håndtere terrormistænkte og sende dem ud af landet. Det var netop risikoen for at blive udsat for tortur og umenneskelig behandling, der var hovedsøjlen i Abu Hamzas kamp mod at blive udleveret til USA.

Det er også Chalal-dommen, der rumsterer $\mathrm{i}$ baggrunden, når eksempelvis en dansk domstol afviser at udvise Niels Holck til Indien med henvisning til, at der er risiko for tortur.

Og det er måske derfor ikke overraskende, at det er med denne dom i tankerne, at Tiger Hanif har brugt præcist den samme begrundelse for, at han ikke burde udleveres fra Stor- 
britannien. Den tidligere grønthandler fra Bolton har henvist til, at han risikerer at blive udsat for tortur og umenneskelig behandling, hvis han skal udleveres til det indiske retssystem.

Tiger Hanif mener desuden, at de $\varnothing$ vrige anklagede i sagen, heriblandt en tidligere minister, der er blevet idømt 20 års fængsel, har tilstået efter at være udsat for tortur, og at de udsagn, der implicerer ham i angrebene i 1983, er blevet fremskaffet på samme måde.

Han har også fremført, at han som muslim risikerer at blive udsat for negativ forskelsbehandling.

Men denne gang er argumenterne ikke bidt på de britiske myndigheder. Det britiske Home Office har sendt en delegation til Gujarat for at se på de faktiske forhold i regionens fængsler og har afvist, at der er nogen risiko for, at Tiger Hanif bliver udsat for tortur eller umenneskelig behandling, hvis han udleveres til myndighederne i Gujarat.

\section{Aftale med undtagelser}

Bliver Tiger Hanif virkelig udleveret til Indien, vil det reelt være første gang, at udleveringsaftalen bliver brugt til at deportere en person, de indiske myndigheder har eftersøgt.

Men det vil ikke være første gang, at Indien forsøger.

I en tidligere sag fra 1999 forsøgte indisk politi at få briterne til at udlevere den kendte Bollywood-kompo- nist Nadeem Saifi, der ifølge myndighederne er mistænkt i en mordsag fra 1997. Her blev den i Indien så kendte kassette-konge Gulsham Kumar skudt ned af tre ukendte gerningsmænd. Det var, mener indisk politi, Nadeem Saifi, der hyrede tre lejemordere til at dræbe en musikalsk konkurrent med henblik på at fremme sin egen karriere.

Inden politiet skred til at arrestere Nadeem Saifi, nåede han at flygte til Storbritannien, hvor han opholdt sig i en årrække og bedyrede sin uskyld i sagen.

Deporteringen blev pure afvist af britisk Højesteret, en afgørelse, der ifølge Times of India formentlig kan have direkte forbindelse til, hvad avisen kalder politiundersøgelsens 'uformåenhed'.

Den succesfulde filmkomponist er nu flyttet til Dubai, hvor han efter eget udsagn 'længes' efter at komme til hjem Indien. Han har flere gange offentligt opfordret myndighederne til at droppe sagen mod ham på grund af mangel på beviser, så han kan flytte hjem. Men det er ikke sket.

\section{Håb om en stime}

Den foreløbige afgørelse i sagen om Tiger Hanif har givet Indien mod på at søge flere deportationer. Den næste i rækken er Ravi Shankaran, der mistænkes for at have deltaget i spionage mod den indiske flåde. Den tidligere officer i flåden forlod den 
indiske hær og oprettede sit eget selskab Shank Ocean Engineering, der levede højt på at få kontrakter med Shankarans tidligere arbejdsplads.

Problemet var bare, ifølge de indiske myndigheder, at han købte informationer fra sine tidligere kolleger, der ulovligt lækkede fortroligt militært materiale, der i den grad gav Ravi Shankaran et forspring i forhold til sine konkurrenter, når det gjaldt om at få lukrative kontrakter med flåden.

I første omgang blev tre ansatte i den indiske flåde arresteret, mens Ravi Shankaran fik lov til at forlade landet i 2005. Så let gik det ikke for hans forretningspartner, der blev pågrebet, netop som han var i færd med at forlade Indien via Indira Ghandi-lufthavnen i New Delhi.

Shankaran slap til Storbritannien, hvor han i en periode har boet hos slægtninge.

Efter de indiske myndigheder har begæret ham udleveret, har han del- vist opholdt sig Sverige og menes for øjeblikket at befinde sig i Moskva, hvor han er på fri fod mod kaution.

Om Shankaran nogensinde når til Indien og bliver stillet for en domstol, kan udvikle sig til en kompliceret international sag.

Og selv om der i Tiger Hanifs tilfælde tilsyneladende kun er den britiske og indiske regering indblandet, er sagen langt fra afgjort.

For uanset om Theresa May er parat til at underskrive deportationspapirerne, er der stadig lang tid til den indiske regering kan gå $\mathrm{i}$ gang med at gøre en celle parat til Tiger Hanif.

Allerede nu har hans advokat ladet forstå, at han er parat til at appellere sagen hele vejen til menneskerettighedsdomstolen i Strassbourg.

Lone Theils er korrespondent om Storbritannien og Irland for dagbladet Politiken. 